\title{
MONOGRÁFICO SOBRE
}

\section{Boca seca, mal aliento y síndrome de boca ardiente. Actualización}

\section{Dry mouth, breath malodour and burning mouth syndrome. Update}

\section{PONENTES}

Andrés Blanco Carrión, Eduardo Chimenos Küstner, Fiorella De luca Monasterio, Enric Jané Salas, José López López, Margarita Martín Martín, Mariona Monfort Codinach, María Eugenia Rodríguez de Rivera Campillo, Xavier Roselló Llabrés

Seminario celebrado el

14 de diciembre de 2013

en Barcelona

Facultad de Odontología. Universidad de Barcelona 


\title{
RESUMEN
}

La xerostomía o boca seca como síntoma y la hiposialia como signo, afecta a la calidad de vida de muchos pacientes y no siempre es diagnostica y tratada de manera adecuada. Sabemos que el síndrome de boca seca es muy frecuente en la población adulta. En recientes estudios, se afirma que el 30\% de la población mayor de 65 años la sufre, y en nuestro país esta cifra supone más de 1,5 millones de personas afectadas con un crecimiento casi exponencial en las próximas décadas. Puede estar producido, entre otras causas, por enfermedades sistémicas y tratamientos oncológicos, destacando de manera especial el consumo de medicamentos. La disminución de saliva se encuentra íntimamente relacionada con dos cuadros frecuentes en patología oral, la halitosis y el síndrome de boca ardiente.

En el presente monográfico que refleja los resultados de un seminario realizado en la Universidad de Barcelona con la colaboración de la empresa Biocosmetics, se actualizan, en primer lugar, los aspectos más relevantes de la boca seca y de la boca ardiente. Después se incide de manera detallada en la etiopatogenia y diagnóstico de la boca seca, la patología oral asociada a la xerostomía y finalmente se actualiza su tratamiento. A continuación se revisa el tratamiento del síndrome de boca ardiente. En una tercera etapa se repasa la etiopatogenia de la halitosis haciendo especial hincapié en la importancia de los compuestos sulfurados y de la cubierta lingual y se actualizan los aspectos terapéuticos. Finalmente se presenta por la doctora Margarita Martín un trabajo que nos repasa de manera específica la xerostomía postradioterapia y nos presenta los resultados de un ensayo clínico en pacientes irradiados que tiene como base el tratamiento con un producto a base aceite de oliva, betaína y xilitol.

Palabras clave: Boca ardiente, boca seca, halitosis, SBA, xerostomía.

\begin{abstract}
Xerostomia or dry mouth as a symptom and hyposalivation as a sign affects the quality of life of many patients and it is not always diagnosed and treated adequately. We know that the dry mouth syndrome is very frequent in the adult population. In recent studies it has been shown that $30 \%$ of the population over 65 years suffers from it, and in our country this figure represents more than 1.5 million affected people, with an almost exponential growth in the coming decades. It can be produced, among other causes, due to systemic diseases and cancer treatments, emphasizing especially on the consumption of medicines. The decrease in saliva is found closely related to two common forms in oral pathology, halitosis and the burning mouth syndrome.

In the present monographic which reflects the results of a seminar held at the University of Barcelona in collaboration with the company Biocosmetics, the most relevant aspects of dry mouth and burning mouth were updated first of all. Afterwards, a detailed account of the etiopathogenesis and diagnosis of dry mouth, oral pathology associated with xerostomia and finally its treatment, were updated. In continuation, the treatment of the burning mouth syndrome was reviewed. In a third stage, the etiopathogenesis of halitosis with particular emphasis on the importance of sulphur compounds and of the lingual cover were reviewed and the therapeutic aspects were updated. Finally Dr. Margarita Martín presented her work specifically reviewing xerostomia postradiotherapy and presented the results of a clinical trial in irradiated patients which is based on treatment with a product containing olive oil, betaine and xylitol.
\end{abstract}

Key words: Burning mouth syndrome (BMS), dry mouth, halitosis, xerostomia

\section{CORRESPONDENCIA}

\author{
Dr. José López López \\ Campus Universitario de Bellvitge \\ Departamento de Odontoestomatología \\ Facultad de Odontología \\ Pabellón de Gobierno \\ Feixa Llarga, s/n \\ 08907 L'Hospitalet de Llobregat \\ Barcelona (España)
}

Correo electrónico: 18575jll@gmail.com 